\title{
Pembuatan tepung porang sebagai upaya peningkatan penjualan umbi porang di masa pandemi covid19
}

\author{
Ika Yuniwati $^{1 *}$, Dian Ridlo Pamuji ${ }^{2}$, Ely Trianasari ${ }^{3}$, Ninik Sri Rahayu ${ }^{4}$, \\ Yuni Ulfiyati ${ }^{5}$
}

${ }^{1}$ Politeknik Negeri Banyuwangi, Indonesia, email:ika@poliwangi.ac.id

${ }^{2}$ Politeknik Negeri Banyuwangi, Indonesia, email:ridlodian@poliwangi.ac.id

${ }^{3}$ Politeknik Negeri Banyuwangi, Indonesia, email:ely.trianasari@poliwangi.ac.id

${ }^{4}$ Politeknik Negeri Banyuwangi, Indonesia, email:ninikrahayu@poliwangi.ac.id

${ }^{5}$ Politeknik Negeri Banyuwangi, Indonesia, email:yuniulfi@poliwangi.ac.id

${ }^{*}$ Koresponden penulis

\section{Info Artikel}

Diajukan: 14 Jan 2021

Diterima: 23 Mei 2021

Diterbitkan: 02 Jun 2021

Keywords:

flour making machine;

porang tubers; quality

Kata Kunci:

mesin penepung; umbi

porang; kualitas

Lisensi:

cc-by-sa

\begin{abstract}
Food sales during the Covid19 pandemic experienced a decline. This also includes Umbi Porang. Kembiritan Village Farmers Group, Genteng District, Banyuwangi Regency is one of the areas in Banyuwangi that produces porang tubers. To solve this sales problem, it is necessary to improve the quality of porang tuber sales by processing porang tubers into the desired shape by consumers. However, the Kembiritan Village Farmer Group cannot process porang tubers into porang flour due to several problems, namely they do not have a machine capable of pounding dry porang chips into porang flour and do not have human resources who can operate machines. Based on these problems, it is necessary to develop a porang tubermaking machine and Human Resources training from partners. This community service began with adjusting the porang tuber-making machine according to the porang tuber at the partner's place. After adjustments were made, training was carried out on the use of the porang flour making machine and the maintenance of the porang tuber-making machine. Then, partner assistance is carried out in determining the quality of porang tuber sales. Where the quality is determined from the capacity per transport of various forms of porang tubers.
\end{abstract}

Abstrak
Penjualan bahan pangan pada masa pandemi Covid19 mengalami
penurunan. Hal tersebut juga termasuk Umbi Porang. Kelompok Tani
Desa Kembiritan Kecamatan Genteng Kabupaten Banyuwangi
merupakan salah satu wilayah di Banyuwangi yang menghasilkan
umbi porang. Untuk mengatasi permasalahan penjualan tersebut
maka perlu dilakukan peningkatan kualitas penjualan umbi porang
melalui pengolahan umbi porang menjadi bentuk yang diinginkan oleh
konsumen. Namun Kelompok Tani Desa Kembiritan tidak dapat
mengolah umbi porang menjadi tepung porang dikarenakan beberapa
permasalahan yaitu belum memiliki mesin yang mampu menumbuk
chip porang kering menjadi tepung porang dan belum memiliki
Sumber Daya Manusia yang dapat mengoperasikan mesin.
Berdasarkan permasalahan tersebut, maka perlu dikembangkan
mesin pembuat tepung umbi porang dan pelatihan Sumber Daya
Manusia dari mitra. Pengabdian masyarakat ini dimulai dengan
penyesuaian mesin pembuat tepung umbi porang yang sesuai dengan


umbi porang di tempat mitra. Setelah dilakukan penyesuaian kemudian dilakukan pelatihan penggunaan mesin pembuat tepung porang serta perawatan mesin pembuat tepung umbi porang. Kemudian dilakukan pendampingan mitra dalam penentuan kualitas penjualan umbi porang. Dimana kualitas tersebut ditentukan dari kapasitas per angkutan berbagai bentuk umbi porang.

\section{PENDAHULUAN}

Kualitas penjualan bahan pangan harus terus menerus ditingkatkan untuk mewujudkan suatu kemandirian industri pangan. Tanaman umbi porang atau yang biasa disebut iles-iles sudah mulai dikembangkan sejak tahun 2014. SOP budidaya pembibitan, pemeliharaan dan pemupukan serta cara percepatan pemanenan dibuat oleh IPB (Santosa, 2014). Khususnya dalam masa pandemi covid19 dibutuhkan strategi peningkatan kualitas penjualan bahan pangan agar terus dapat memberikan penghasilan kepada para kelompok tani. Strategi tersebut meliputi faktor internal dan faktor eksternal. Untuk peningkatan kualitas tersebut dapat dilakukan dengan peningkatan kualitas mutu sumber daya manusia (SDM) dan peningkatan sarana serta prasarana pada teknologi pertanian (Fatimah \& DM, 2016).

Adanya Surat Edaran (SE) dari Pemerintah mengenai kebijakan social distancing dan physical distancing, dimana seluruh masyarakat harus menerapkannya. Petani di Banyuwangi-pun ikut melaksanakan social distancing demi kesehatan bersama. Para Petani lebih banyak melakukan aktivitas dirumah dibandingkan dengan aktivitas di lahan pertanian. Hal ini memberikan dampak adanya penurunan baik produksi maupun penghasilan pertanian di Banyuwangi. Banyuwangi terletak di ujung paling timur dari Pulau Jawa. Daerah ini memiliki tanah yang subur untuk ditanami berbagai komoditas tumbuhan. Salah satunya adalah umbi-umbian. Sebagian umbiumbian yang ditanam adalah umbi yang dapat diolah menjadi makanan. Pengolahannya terbagi menjadi beberapa jenis salah salah satunya pembuatan tepung. Selain itu bentuk umbi porang dalam bentuk tepung dapat menggantikan penggunaan tepung-tepung yang lain diantaranya tepung terigu atau berbagai olahan pangan yang berbasis tepung. Bentuk umbi porang dalam bentuk tepung porang memiliki waktu penyimpanan cukup lama dan dapat dimanfaatkan menjadi berbagai bahan baku baik dalam industri pangan maupun industri non pangan (Efendi et al., 2015).

Tepung dari umbi-umbian seperti kentang, dan singkong telah banyak dipasarkan di Indonesia, tetapi hasilnya masih mengandung banyak kadar glukosa dan lemah tinggi sehingga tidak dapat dikonsumsi oleh penderita penyakit kardiovaskular (CVD). Penyakit kardiovaskuler menjadi salah satu penyebab kematian bagi penduduk di dunia. Kurang lebih 17,3 juta penduduk dunia yang berusia kurang dari usia 60 tahun meninggal akibat penyakit tersebut. Adapun kematian yang dimaksudkan khususnya penyakit jantung koroner dan stroke (Hadi et al., 2016). Pola hidup sehat dapat merupakan salah satu pencegahan dalam risiko penyakit kardiovaskuler. Hal yang dapat dilakukan dengan mengganti pola makan yaitu konsumsi makanan yang rendah lemak. Selain itu didukung peningkatan konsumsi makanan yang kaya 
akan serat. Makanan tersebut dapat diperoleh dari tepung umbi porang (Mahirdini \& Afifah, 2016).

Porang adalah tumbuhan semak herbal yang berumbi dalam tanah dan dapat ditemukan di kawasan hutan (Saleh et al., 2015; Sitompul et al., 2018). Umbi porang atau yang disebut dengan nama ilmiah Amorphophalus paeniifolius (Dennst) Nicolson merupakan salah satu tumbuhan yang dapat dimanfaatkan sebagai bahan makanan, tanaman hias, obat-obatan, dan keripik. Sebagai bahan makanan dan obat-obatan, bagian tumbuhan yang dapat diambil diantaranya daunnya, batangnya serta umbinya. Umbi porang memiliki kemiripan dengan suweg, dapat juga dikonsumsi secara langsung (Setiawati et al., 2017; Wahyuni et al., 2020).

Tepung porang merupakan umbi porang (Amorphophallus muelleri Blume) yang dilakukan proses pengolahan mulai dari penjemuran hingga penumbukan. Pada bentuk tepung porang, umbi porang memiliki masa simpan yang relatif lebih panjang Panjang. Sehingga tepung porang mulai dilakukan pengembangan di industri-industri pangan. Tepung porang memiliki kadar glukomanan yang relatif cukup tinggi sebesar $64.98 \%$. Glukomanan adalah serat pangan yang larut air dan memiliki sifat hidrokoloid yang kuat serta rendah kalori. Glukomanan juga memiliki sifat fisik yang istimewa yaitu mampu mengembang dalam air hingga 138-200 \% (Widjanarko et al., 2015). Hasil penelitian menunjukkan proporsi terbaik tepung porang $3 \%$ dan tepung maizena $22 \%$, percampuran ini memiliki karakteristik rendemen $91.90 \%$, kadar air $70.25 \%$, kadar pati $8.49 \%$, WHC $68.44 \%$, kadar lemak $5.68 \%$, kadar oksalat $1.38 \%$, kadar glukomanan $43.74 \%$ dan kekenyalan $8.80 \mathrm{~N}$. Sebelum menjadi tepung, umbi porang dijemur dulu hingga kering (Anggraeni et al., 2014).

Kelompok Tani Desa Kembiritan menghasilkan setiap musim kurang lebih 100 ton umbi porang/enam bulan. Umbi porang yang mengandung glukomanan tinggi, dapat digunakan sebagai bahan baku untuk industri pangan, kesehatan dan industri lainnya (Panjaitan et al., 2016). Gambar Umbi Porang yang dihasilkan Kelompok Tani Desa Kembiritan dapat dilihat pada gambar 1.

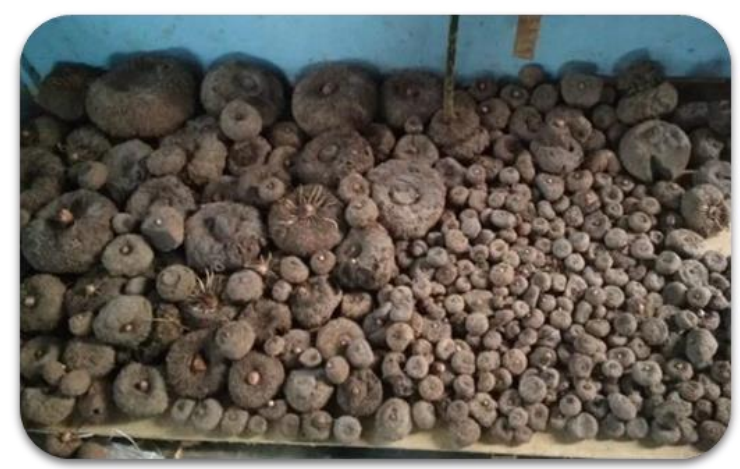

Gambar 1. Hasil Panen Umbi Porang Mitra 
Total pendapatan sekali panen pada Kelompok Tani Desa Kembiritan kurang lebih sebesar Rp. 500.000.000,-. Biaya operasional dalam sekali panen kurang lebih sebanyak Rp. 200.000.000,-. Harga Jual umbi porang basah antara Rp. 5.000,- hingga Rp. 12.000,. Sedangkan harga jual umbi porang kering/chip dari pihak Kelompok Tani Desa Kembiritan antara Rp. 35.000,- hingga Rp. 50.000,-. Adapun chip porang mitra dapat dilihat pada gambar 2. Harga tersebut kurang lebih sama dengan harga chip porang yang dijual oleh Masyarakat Desa Jembul (Puspitorini et al., 2019).

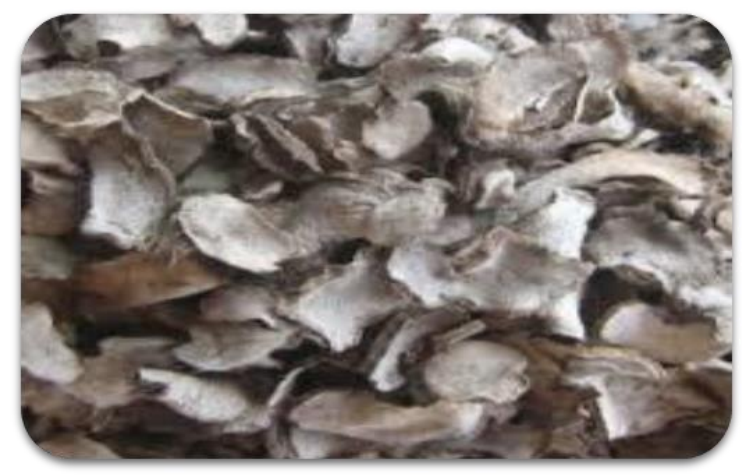

Gambar 2. Umbi Porang dalam Bentuk Chip

Hasil dari survei dan observasi pendahuluan, Kelompok Tani Desa Kembiritan menjual umbi porang dalam bentuk basah maupun dalam bentuk umbi porang kering. Untuk bentuk kering/chip porang akan dikirimkan ke Jakarta maupun ke luar negeri dengan harga yang relatif murah.

Beberapa distributor meminta Kelompok Tani Desa Kembiritan untuk mengolah umbi porang menjadi tepung. Hal itu terutama pada Pandemi dan Pasca Pandemi Covid19, dimana dibutuhkan bahan jadi atau setengah jadi yang memudahkan konsumen. Kebutuhan akan tepung porang juga semakin meningkat dari waktu ke waktu. Hal tersebut dikarenakan fungsi tepung porang yang dapat digunakan sebagai bahan baku pembuatan mie dan kosmetik. Peluang Pemasaran di luar negeri seperti ekspor di negara Jepang, Taiwan, dan Korea merupakan pasar yang cukup menjanjikan (Sari \& Suhartati, 2015). Namun Kelompok Tani Desa Kembiritan ini tidak dapat mengolah umbi porang menjadi tepung porang dikarenakan beberapa permasalahan yaitu belum memiliki mesin yang mampu menumbuk chip porang menjadi tepung porang dan belum memiliki SDM yang dapat mengoperasikan mesin/membuat tepung porang.

\section{METODE PELAKSANAAN}

Adapun proses pelatihan tepung umbi porang ini melalui beberapa tahapan kegiatan antara lain melakukan penyesuaian mesin pembuat tepung umbi porang. Kemudian melakukan pelatihan pembuatan tepung umbi porang dan sosialisasi perawatan mesin pembuat tepung umbi porang. Serta mendata kualitas penjualan umbi porang mitra. Pada proses pertama, 
kegiatan yang dilakukan meliputi pembuatan skema pemodelan dan desain mesin yang sesuai dengan kondisi mitra. Hal tersebut dilakukan untuk mengetahui posisi komponen-komponen, ukuran, dan bentuk alat yang akan memudahkan dalam proses penyesuaian mesin pembuat tepung porang sehingga tidak menyimpang dari rencana awal. Kemudian dilakukan persiapan alat dan bahan yang akan digunakan. Pemilihan komponen ditinjau dari segi harga dan kualitas barang yang digunakan menyesuaikan kondisi mesin yang dibutuhkan mitra dalam pembuatan tepung porang nantinya. Setelah melakukan pendesainan dan persiapan alat/bahan, langkah berikutnya yaitu melakukan penyesuaian mesin.

Setelah mesin pembuat tepung porang terselesaikan sesuai dengan desain yang dirancang langkah berikutnya yaitu pelatihan pembuatan tepung porang dan sosialisasi perawatan mesin pembuat tepung porang. Tujuan dari kegiatan ini yaitu memberikan tambahan keterampilan kepada kelompok Tani Desa Kembiritan dalam peningkatan kualitas produk yang dijualnya. Setelah dilakukan pelatihan pembuatan tepung porang kemudian dilakukan sosialisasi perawatan mesin. Sosialisasi tersebut bertujuan agar mesin yang nantinya diberikan kepada mitra dapat dipergunakan dengan maksimal.

\section{HASIL DAN PEMBAHASAN}

Desa Kembiritan yang terletak sekitar $20 \mathrm{KM}$ dari Politeknik Negeri Banyuwangi, merupakan wilayah penanaman umbi porang. Kelompok Tani Desa Kembiritan cukup bergantung dengan hasil panen umbi porang. Untuk mengatasi permasalahan ekonomi pasca Pandemi Covid19 tersebut maka perlu dilakukan inovasi-inovasi terkait peningkatan penghasilan para pedagang. Salah satu inovasi yang dikembangkan dalam pengabdian ini yaitu mengolah umbi porang menjadi tepung umbi porang. Tepung Umbi Porang memiliki harga antara Rp. 150.000,- hingga Rp. 200.000,- per kg. Harga tersebut 30 kali lipat dari umbi porang basah dan 3 kali lipat dari chip porang. Namun Kelompok Tani Desa Kembiritan ini tidak dapat mengolah umbi porang menjadi tepung porang dikarenakan beberapa permasalahan yaitu belum memiliki mesin yang mampu menumbuk chip porang kering menjadi tepung porang dan belum memiliki SDM yang dapat mengoperasikan mesin/membuat tepung porang.

Berdasarkan permasalahan yang dihadapi oleh mitra, maka perlu dilakukan penyesuaian mesin pembuat tepung umbi porang yang sesuai dengan kebutuhan mitra. Mesin pembuat tepung umbi porang yang dikembangkan dan dirancang untuk tetap mengutamakan keselamatan dan keamanan bagi operator mesin, sehingga para pembuat tepung porang dapat lebih mudah melakukan pengolahan umbi porang menjadi tepung porang sekaligus menjamin keselamatan para pekerja. Setelah melakukan penyesuaian mesin serta pengembangannya sesuai dengan kondisi mitra maka dilakukan proses pelatihan pembuatan tepung porang oleh tim pelatih seperti nampak pada gambar 3 . 


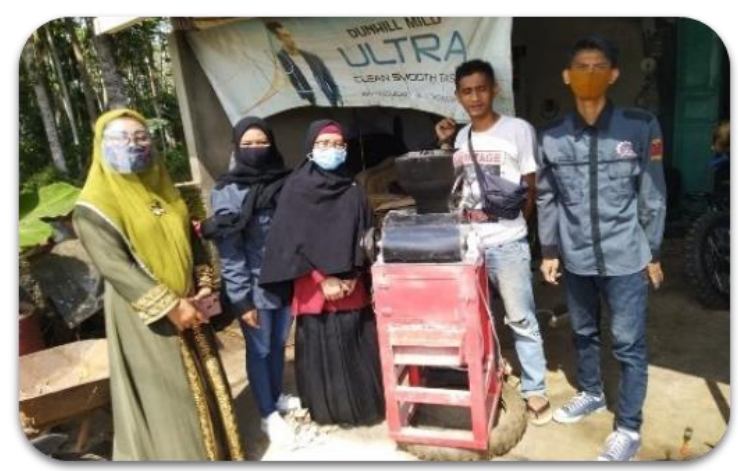

Gambar 3. Tim Pelatihan Pembuatan Tepung Porang

Pelatihan pembuatan tepung porang diawali dengan mencontohkan cara pembuatan tepung porang oleh Tim Pelatihan seperti pada Gambar 4. Chip porang kering dimasukkan kedalam hooper input kemudian kunci pintu pemantau porang, pasang kantong pada bagian hopper output. Setelah itu dinyalakan tombol on dan operator mengatur pintu masuk chip porang kedalam tabung hammer mill, agar penumbukan chip porang terjadi dengan sempurna dan tidak melebihi batas tumbukan. Mitra mengikuti cara yang sama dalam proses pelatihan.

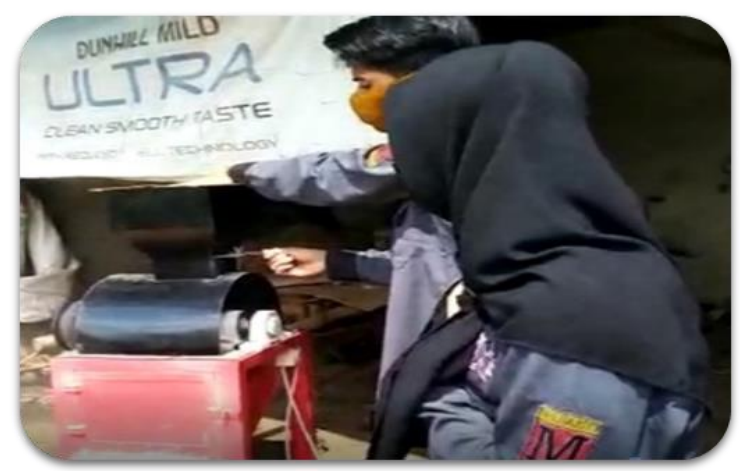

Gambar 4. Proses Pelatihan Pembuatan Tepung Porang

Hasil dari pelatihan pembuatan tepung porang dapat dilihat pada gambar 5. Tepung porang yang dihasilkan pada pelatihan ini disesuaikan dengan tingkat kehalusan tepung porang yang diinginkan oleh perusahaan yang telah bekerjasama dengan mitra. 


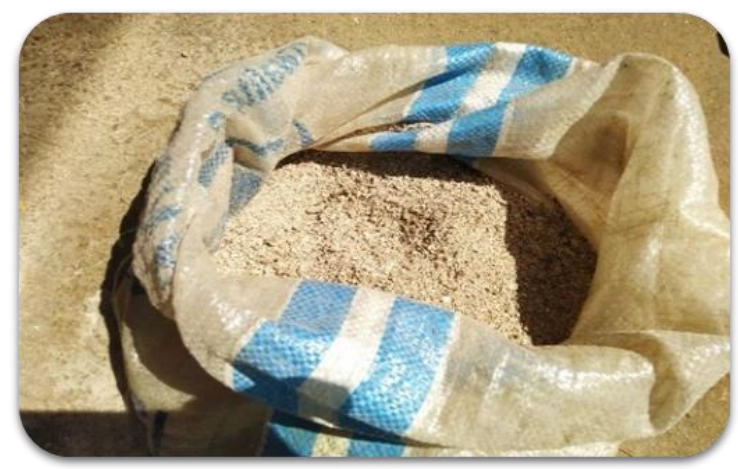

Gambar 5. Hasil Pelatihan Pembuatan Tepung Porang

Setelah dilakukan pelatihan pembuatan tepung porang kemudian dilanjutkan sosialisasi perawatan mesin seperti pada gambar 6. Pada proses sosialisasi perawatan mesin dijelaskan proses pembersihan mesin setelah dilakukan pemakaian serta komponen-komponen yang akan berkarat dalam jangka pemakaian antara 5-10 tahun.

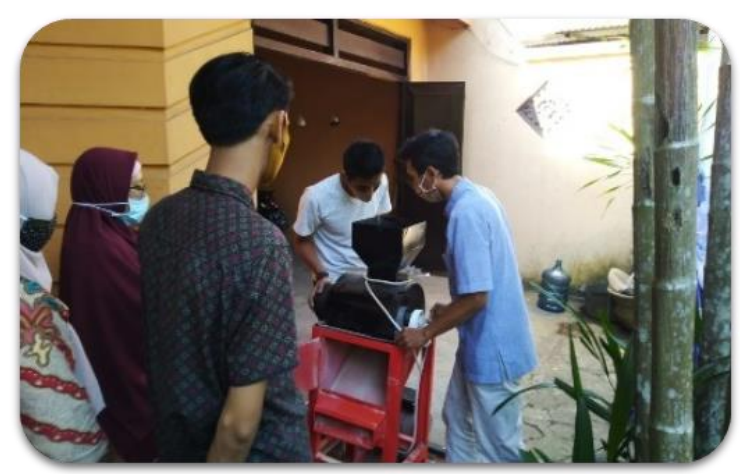

Gambar 6. Sosialisasi Perawatan dan Serah Terima Mesin

Setelah dilakukan proses sosialisasi perawatan mesin kemudian dilakukan serah terima mesin. Adanya proses serah terima mesin pembuat tepung porang tersebut diharapkan dapat bermanfaat secara berkelanjutan untuk kelompok tani umbi porang di daerah Kembiritan. Proses serah terima dapat dilihat pada gambar 7 . 


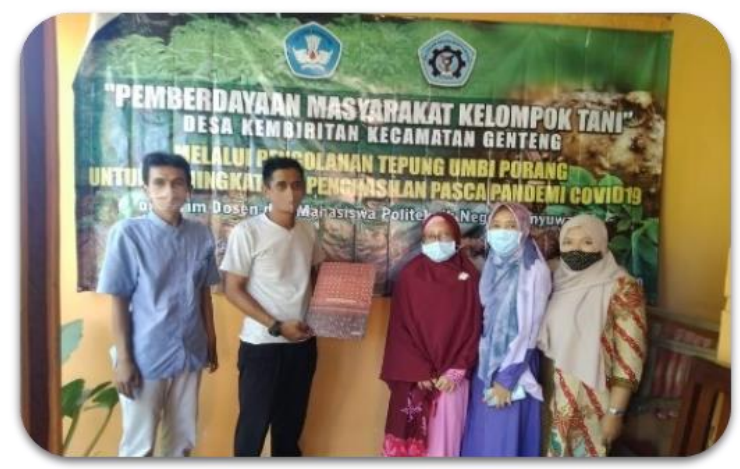

Gambar 7. Sosialisasi Perawatan dan Serah Terima Mesin

Selain itu diharapkan dengan adanya mesin tersebut, juga dapat meningkatkan kualitas penjualan kelompok tani umbi porang. Hal itu dikarenakan yang awalnya menjual porang dalam bentuk chip, sekali pengiriman hanya sekitar 4 ton ketika berbentuk tepung sekali pengiriman sampai 7 ton. Grafik keuntungan masing-masing bentuk penjualan dapat dilihat pada gambar 8 .

\section{Keuntungan Penjualan Umbi Porang Dalam Berbagai Bentuk Produksi}

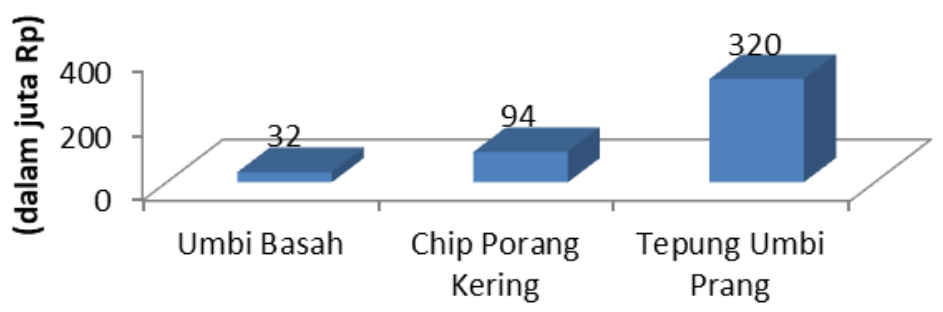

Gambar 8. Keuntungan Penjualan Umbi Porang

Pada grafik tersebut dapat diketahui dalam satu kali pengangkutan untuk umbi basah akan memperoleh keuntungan sebesar Rp. 32.000.000,-. Sedangkan untuk penjualan chip porang kering, mitra mendapatkan keuntungan sekitar Rp. 94.000.000,-. Untuk bentuk tepung porang keuntungan meningkat sekitar 3-4 kali lipat dari penjualan umbi basah dan chip porang kering kurang lebih sebesar Rp. 320.000.000,-.

\section{KESIMPULAN}

Kegiatan program pengabdian kepada masyarakat (PKM) yang telah dilaksanakan memberikan kesimpulan bahwa partisipasi mitra cukup tinggi pada kegiatan pelatihan pembuatan tepung porang dan sosialisasi perawatan mesin penepung. Mitra mampu meningkatkan kualitas penjualan umbi porang dengan adanya mesin yang telah dikembangkan oleh tim pelaksana Politeknik Negeri Banyuwangi. Para petani di Kelompok Desa 
Kembiritan dapat melakukan proses pembuatan tepung umbi porang, sehingga proses produksi tepung porang dapat berjalan baik. Adanya inovasi pengolahan umbi porang diharapkan dapat meningkatkan penghasilan petani dibandingkan penjualan umbi porang pada waktu-waktu sebelumnya.

\section{UCAPAN TERIMA KASIH}

Ucapan terima kasih yang sebesar-besarnya kami tujukan kepada Politeknik Negeri Banyuwangi yang telah memberi bantuan pendanaan pada kegiatan hibah pengabdian kepada masyarakat melalui Pusat Penelitian dan Pengabdian Kepada Masyarakat Politeknik Negeri Banyuwangi. Serta ucapan terima kasih kepada seluruh tim pendukung terlaksananya kegiatan ini.

\section{DAFTAR RUJUKAN}

Anggraeni, D. A., Widjanarko, S. B., \& Ningtyas, D. W. (2014). Proporsi Tepung Porang (Amorphophallus Muelleri Blume): Tepung Maizena Terhadap Karakteristik Sosis Ayam. J. Pangan Dan Agroindustri, 2(3), 214-223. https://jpa.ub.ac.id/index.php/jpa/article/view/70

Efendi, Z., Surawan, F. E. D., \& Winarto. (2015). Efek Blancing dan Metode Pengeringan Terhadap Sifat Fisikokimia Tepung Uni Jalar Orange (Ipomoea batatas L.). Jurnal Agroindustri, 5(2), 109-117. https://core.ac.uk/download/pdf/228573726.pdf

Fatimah, \& DM, I. H. (2016). Strategi Peningkatan Produksi Subsektor Tanaman Pangan Di Kabupaten Kudus. Journal Of Public Policy And Management Review, 5(2), 38-54. https://ejournal3.undip.ac.id/index.php/jppmr/article/view/10768

Hadi, N. S., Farmawati, A., \& Ghozali, A. (2016). Pencegahan Hipertensi dan Penebalan Dinding Aorta dengan Pemberian Kecambah Kacang Hijau (Phaseolus Radiatus (L)) pada Tikus Putih Sprague Dawley. Jurnal Gizi Klinik Indonesia, 12(3), 116. https://doi.org/10.22146/ijcn.22454

Mahirdini, S., \& Afifah, D. N. (2016). Pengaruh substitusi tepung terigu dengan tepung porang (amorphophallus oncopphyllus) terhadap kadar protein, serat pangan, lemak, dan tingkat penerimaan biskuit. Jurnal Gizi Indonesia (The Indonesian Journal of Nutrition), 5(1), 42-49. https://doi.org/10.14710/jgi.5.1.42-49

Panjaitan, T. W. S., Rosida, D. A., \& Widodo, R. (2016). Aspek Mutu Dan Tingkat Kesukaan Konsumen Terhadap Produk Mie Basah Dengan Substitusi Tepung Porang. HEURISTIC: Jurnal Teknik Industri, 14(1), 1-16. https://doi.org/10.30996/he.v14i01.1040

Puspitorini, P. S., Cahyono, P. A., \& Admiral, E. (2019). Pemberdayaan Masyarakat Jembul dengan Teknologi Tepat Guna Pengolahan Chips porang dalam Meningkatkan Daya Saing. International Journal of Community Service Learning, 3(4), 244-251. https://doi.org/10.23887/ijcsl.v3i4.15723

Saleh, N., Rahayuningsih, S. ., Radjit, B. S., Ginting, E., Harnowo, D., \& Mejaya, I. M. J. (2015). Tanaman Porang Pengenalan, Budidaya dan Pemanfaatannya. In Pusat Penelitian dan Pengembangan Tanamaan 
Pangan. Badan Penelitian dan Pengembangan Pertanian. Pusat Penelitian dan Pengembangan Tanaman Porang.

Santosa, E. (2014). Pengembangan Tanaman Iles-lles Tumpangsari Untuk Kesejahteraan Petani Dan Kemandirian Industri Pangan Nasional. Risalah Kebijakan Pertanian Dan Lingkungan: Rumusan Kajian Strategis Bidang Pertanian Dan Lingkungan, 1(2), 73. https://doi.org/10.20957/jkebijakan.v1i2.10288

Sari, R., \& Suhartati. (2015). Tumbuhan Porang: Prospek Budidaya Sebagai Salah Satu Sistem Agroforestry. Buleting EBONI, 12(2), 97-110. https://doi.org/10.20886/buleboni.5061

Setiawati, E., Bahri, S., \& Razak, A. R. (2017). Ekstraksi Glukomanan dari Umbi Porang (Amorphophallus paeniifolius (Dennst.) Nicolson). Kovalen, $3(3)$,

234. https://doi.org/10.22487/j24775398.2017.v3.i3.9332

Sitompul, M. R., Suryana, F. S., Mahfud, M., \& Bhuana, D. S. (2018). Ekstraksi Asam Oksalat pada Umbi Porang (Amorphophallus Oncophyllus) dengan Metode Mechanical Separation. Jurnal Teknik ITS, 7(1), 135-137. https://doi.org/10.12962/j23373539.v7i1.28831

Wahyuni, K. I., Rohmah, M. K., Ambari, Y., \& Romadhon, B. K. (2020). Pemanfaatan Umbi Porang (Amorphophallus muelleri BI) Sebagai Bahan Baku Keripik. Jurnal KARINOV, 3(1), 1. https://doi.org/10.17977/um045v3i1p1-4

Widjanarko, S. B., Widyastuti, E., \& Rozaq, F. I. (2015). Pengaruh Lama Penggilingan Tepung Porang (Amorphophallus Muelleri Blume) dengan Metode Ball Mill (Cyclone Separator) terhadap Sifat Fisik dan Kimia Tepung Porang. Jurnal Pangan Dan Agroindustri, 3(3), 867-877. https://jpa.ub.ac.id/index.php/jpa/article/view/208 